November 2013

\title{
Love and belonging: Strategies to help mentally ill patients
}

Shirin Rahim

Aga Khan University, shirin.rahim@aku.edu

Follow this and additional works at: https://ecommons.aku.edu/pakistan_fhs_son

Part of the Nursing Commons

\section{Recommended Citation}

Rahim, S. (2013). Love and belonging: Strategies to help mentally ill patients. i-Manager's Journal on Nursing, 2(4), 34-37. Available at: https://ecommons.aku.edu/pakistan_fhs_son/115 


\title{
LOVE AND BELONGING: STRATEGIES TO HELP MENTALLY ILL PATIENTS
}

\author{
By \\ SHIRIN RAHIM \\ M.Sc N, Aga Khan University, School of Nursing and Midwifery, Karachi.
}

\begin{abstract}
ABSTRACT

Love and belonging is a concept, used by Abraham Maslow (a humanistic psychologist) in his motivation theory. Love and belonging is one of the human needs in Maslow's hierarchy and required to be fulfilled in order to achieve self actualization. According to Lisbeth (2003) "Because of the social nature of humans and the long developmental period from birth to adulthood, the need for love and belonging is closely linked to the need for survival" (p. 128). If a child is left with unmet need of love and belonging, he may feel difficulties in forming lasting relations in future also and may get deprived of love and belongingness for all of his life. This deprivation can lead to unhealthy personality development and affect person's mental health adversely. This concept is very well explained in choice theory given by William Glasser (1998). The choice theory states that "we are driven by our genes to satisfy five basic needs: survival, love and belonging, power, freedom and fun. In practice, the most important need is love and belonging, as it is a requisite for satisfying all of the needs. "Glasser (1998) further says that "Choice theory, replaces Seven Caring Habits, with the Seven Deadly Habits." This paper will attempt to integrate the choice theory, with one of the patient's scenario and suggest evidence based implementation strategies to help such patients.
\end{abstract}

Keywords: Love and Belonging, Choice Theory, Mas/ow's Hierarchy of Basic Human Needs.

\section{INTRODUCTION}

Love and belonging is a concept, used by Abraham Maslow (a humanistic psychologist) in his motivation theory. Maslow has talked about hierarchy of human needs starting with physiological needs of food and shelter and finishes at the need of self actualization. Love and belonging is one of the human needs in Maslow's hierarchy and required to be fulfilled in order to achieve self actualization. According to Sarma \& Hoek (2004) "Maslow claimed that human beings are motivated by unsatisfied needs, and that certain lower needs, need to be satisfied before higher needs can be satisfied." Sarma and Hoek (2004) further say that" The need for love require giving and receiving affection. When they are unsatisfied, loneliness, ostracism, rejection, friendlessness, and rootless ness are preeminent." Lisbeth (2003) explained the need of love and belonging and says that "Because of the social nature of humans and the long developmental period from birth to adulthood, the need for love and belonging is closely linked to the need for survival." Lisbeth (2003) quotes
Glasser in saying that

The need for love and belonging includes the range of intimacy between/among people and encompasses caring, compassion, empathy, attention, and affection range of closeness between people, getting attention and affection of parents and other family members and, a sense of having a place in the world, feeling accepted and approved versus rejection and disapproval.(p.56)

The concept of love and belonging and its satisfaction is very well explained in choice theory given by William Glasser (1998). This paper is an attempt to analyze love and belonging in light of the choice theory, integrating choice theory with one of the patient's scenario and suggest evidence based implementation strategies to help such patients.

\section{Love and belonging and choice theory}

Love and belonging being one of the human needs has its roots in satisfactory and successfull inter personal relationship and these two forms a vicious circle. If a child is 
left with unmet need of love and belonging due to ineffective or unsuccessful interpersonal relationship in his early life, he may feel difficulties in forming lasting relations in future also and may get deprived of love and belongingness for all of his life. This deprivation can lead to unhealthy personality development and affect person's mental health adversely and person may end having a mental illness.

The concept of love and belonging and its satisfaction can be understood through the Choice Theory given by William Glasser (1998). According to Glasser (1998) Choice theory states that "we are driven by our genes to satisfy five basic needs: survival, love and belonging, power, freedom and fun. In practice, the most important need is love and belonging, as it is a requisite for satisfying all of the needs. Love here means both giving as well as accepting love of significant others." Glasser (1998) further says that "Choice theory, replaces the Seven Deadly Habits (criticizing, blaming, complaining, nagging, threatening, punishing, bribing/rewarding to control), with the Seven Caring Habits (supporting, encouraging, listening, accepting, trusting, respecting, negotiating differences). The seven deadly habits are destructive to relationships and will result in a disconnection. Being disconnected is the source of almost all human problems such as what is called mental illness, drug addiction, violence, crime, school failure, spousal abuse, to mention a few."

The choice theory gives us an idea that love and belonging is one of the basic and the most important human need which can be fulfilled by having a strong interpersonal relationship, with all the seven caring habits and avoiding the seven deadly ones. It is these deadly habits when comes in any relationship then that relationship gets disconnected. It endangers the satisfaction of the need for love and belonging and the person ends up in having mental illness.

\section{Patient's Scenario}

This paper will attempt to integrate the choice theory with the following patient's scenario. Mr. X, a 64 years old patient is diagnosed as schizophrenic since last 40 years. He had multiple admissions to hospital but this time he got admitted a week before I met him. While conversation the client disclosed that at the age of 10 patient's mother died and with his five other siblings he was brought up by his grandmother. The client's father did not remarry due to the fear of the bad attitude of the step mother towards his children. Being elder of all the siblings the client spent many of his life years looking after and taking care of his younger brothers and sisters. He started missing the love and affection of his mother and this emptiness hindered with his over all life. He quit studies as he could not concentrate on his studies. He also had difficulty in doing office jobs and therefore he frequently kept on changing his jobs also. Later he got married and had one daughter but his wife left him as he was not earning properly and remained unemployed for many years. Now he is depressed and de motivated, shows withdrawal symptoms, has stopped talking to anyone, stopped eating, and does not pay attention to self hygiene etc.

\section{Integration of choice theory in patient's scenario}

It is evident from the scenario that the client has been failed to fulfill his need of love and belonging. Initially his mother's death made him deprived of her love. Then being eldest, he took the heavy responsibility of taking care of his siblings along with his grand mother, but he himself did not receive enough attention. May be his father or grand mother have never treated him with the seven caring habits in his childhood, and rather he was exposed to the seven deadly habits. That is why he never got satisfaction in his relationships which kept on depriving his needs of love and belonging and eventually he ended up in having mental illness as early as 24 years of age. Then, when he got married he was unable to continue the relationship. His divorce may be the result of his mental illness to some extent but to greater extent due to the fact that the client was probably not able to give the sense of love and belongingness to his wife as his own need of love and belonging was not fulfilled. Probably he could not have developed the seven caring habits and may have used seven deadly habits of choice therapy which resulted in ending his relationship with his wife.

\section{Interventional Strategies}

Now as this client is hospitalized considering all his symptoms in context of the concept of love and 
belonging, some health promotion strategies can be developed to help the client deal with the issue and to prevent further deterioration of mental health. These strategies can be divided into three category namely individual, group, and institutional level.

\section{Strategy at individual level}

The individual strategy which can be beneficial in this case is psychodynamic nursing approach which can be carried out on one to one basis between a nurse and the client. According to Rigby and Alexander (2008) "The basic tenet of psychodynamic approaches is that the patient forms a therapeutic relationship with a professional and talks about his or her feelings." (p.54). Rigby and Alexander (2008) further says that in "psychotherapy nurse uses therapeutic relationship and concentrates on encouraging patients to look at coping with the symptoms and reducing the effects the illness has on their lives." (p.54) Hildegard Peplau (1991) provides a framework for psychodynamic nursing. According to Townsend (2006) "Paplau provides nurses with the framework for psychodynamic nursing to interact with clients, many of whom are fixed in -or because of illness have regressed to - an earlier level of development."(p.47). Townsend (2006) further says that "Paplau suggests roles of a counselor, a teacher, a resource person and a leader that nurses may assume to assist their client to progress ,thereby achieving or resuming their appropriate developmental level" (p.47). Based on the above explanation most of these roles can be assumed by a nurse to help the client promote his mental health. The client may be taught ways for ventilation of feelings, relaxation technique (deep breathing exercise) and taking help from nature, and religion at times when client is worried and anxious. According to Culliford (2005) "Comprehensive research evidence shows that religious and spiritual beliefs and practices help prevent many physical and mental illnesses, reducing both symptom severity and relapse rate, speeding up and enhancing recovery, as well as rendering distress and disability easier to endure."(p. 1).

\section{Strategy at group level}

The strategy on group level I would be to involve client's family in his treatment and try to train and empower his family members by education sessions so that they can participate in client's recovery. This may help client in fulfilling his need of belongingness and being loved by the family. According to Rigby and Alexander (2008) "The efficacy of family work for the patients with schizophrenia is well established which results in reduced relapse rates, improved medication concordance and possible reduction in social impairment."(p.54)

\section{Strategy at institutional level}

When it comes on institutional level, Carl Roger's client centered therapy will work best with this client. Jamson (2005) describes Carl Roger Client Centered Therapy Rogers' method of counseling. According to this therapy the client (not called a patient) takes responsibility for the direction of the therapy and is completely responsible for making changes. The therapist cannot make changes for the client. The counselor makes sure the conditions for change are present. Client is considered responsible and capable rather than sick. The client moves through the 5 steps to change, feeling free to express the self and move from blaming to making "I" statements. The 5 Steps of the Counseling Process -1 ) release of pent up emotions and irrational thoughts, 2) catharsis, the breakthrough period, 3) acceptance, 4) insight, and 5) the development of a framework for a positive self action. The three critical attitudes or values in Person or Client-Centered Therapy are unconditional positive regard, empathy and genuineness (congruence).

\section{Conclusion}

To conclude it can be said that love and belonging being a human need is a sensitive and most important issue to be dealt with in caring for mentally ill patients. Being a health care provider it is our responsibility to help clients resolve the issue of unmet need of love and belonging by using the above mentioned strategies. The choice therapy can be a nice guide to assess clients needs of love belongingness and psychodynamic and client centered nursing can be the useful approaches for implementing strategies to help clients fulfill the need.

\section{References}

[1]. Culliford, (2005). Healing from Within: Spirituality and Mental Health. Retrieved on March 28, 2009. from 


\section{CASE STUDY}

www.rcpsych.ac.uk/college/sig/spirit/publications/index.ht $\mathrm{ml}$.

[2]. Glasser (1998). Choice Theory: A New Psychology of Personal Freedom, The William Glasser Institute. Retrieved on March 28, 2009 from http://www.wglasser.com/ index.php?option =com_content\&task = view\&id $=12 \&$ lte $\operatorname{mid}=27$.

[3]. Jamson, J. (2005). Important Terms for Understanding Carl Roger's Theory and Client Centered Therapy. Retrieved on March 28, 2009. from www. H: IPsych $\mid \mathrm{B} \backslash$ Humanistic $\backslash$ Rogers Terms.doc.

[4]. Lisbeth, K. (2003). Choice Theory Instructional Module
Retrieved on March 28, 2009 From http://www.personal. kent.edu/ Ikjusti1/Choice_Theory/love_belonging.htm.

[5]. Rigby, P. \& Alexander, J. (2008). Understanding schizophrenia. Nursing Standard 22 (28). 49-56.

[6]. Sappington, J.Y. (2003). Nurturance: The Spirit of Holistic Nursing Journal of Holistic Nursing 21 (8) 8-19.

[7]. Sarma, A. \& Hoek, A. (2004). A Need Hierarchy for Teams :Technical Report: UCI-ISR-04-9 Department of Informatics University of California Irvine.

[8]. Townsend, M.C. (2006). Psychiatric mental health nursing:Concepts of care in evidenced based practice (5 th ed.). Philadelphia:Lippincott.

\section{ABOUT THE AUTHOR}

M.Sc N, Aga Khan University, School of Nursing and Midwifery, Karachi. 